\title{
Islamic Concept of Mental Health
}

\author{
Abdul Hayy Alawi, M.S. \\ Lahore, Pakistan
}

DOI: http://dx.doi.org/10.5915/22-3-14306

\begin{abstract}
Some studies have indicated that psychological stress, an outcome of modern civilization, is associated with deterioration of mental health. In order 10 regain mental health, people in vain turn for help to the advocates of current psycholagical models viz. the behavioristic, the dynamic, or the humanistic ones. All these models have made limited contributions since they have an erroneous view of human nature. A need is felt for a model which is based upon "the original" nature of mun. This model, having the divine teachings as its source, is the Istamic one. Man is created in the best of stature because he possesses godly qualities within him. He only falls from this status when he disregards the goals of his life. Since all creation obey the laws of nature, all are unconsciously' Muslims. The difficulty arises when man, who has the conscious aspect as well, refuses complete subinission 10 his creator. This conflict results in loss of mental health. The concept of repression has no place in this model because in it, human urges are neither neglected nor given undue importance. Some Muslim psychologists may perhaps find a reinforcement for this model by testing the hyporhesis that the Muslim societies have far less mental health problems than the non-Muslim societies.
\end{abstract}

Key words: Psychological stress, mental health, Islamic concept, psychological models.

The present century is the age of science and technology; man no longer remains a slave of his environment. He has, with the help of his scientific achievements, created a new world, a world in which different goals of life with different value systems have emerged. The remarkable progress man has made has resulted in shattering his personal as well as his social life. The technical revolution has severely blocked his efforts to seek the "good life". It seems that modern civilizasion and its associated psychological stress has, in spite of its innumerable comforts, given man disordered behavior. This can be observed in the form of his personal distress,

From the Department of Applied Psychology

University of the Punjab

Lahore, Pakistan.

Reprint Reques's: Abdul Hayy Alawi, M.S.

Depariment of Applied Psychology

University of the Punjab

Lahore, Pakistan. disabling behavior tendencies, poor reality control, depression, and psychosomatic disorders. In other words, he has lost his mental health and finds no peace of mind. In order to regain his mental health he is anxiously looking for devices that can give back and promote mental health.'

But what exactly is meant by "mental health"? In spite of its wide use, it is not easy to define this term. Psychologists gencrally emphasize its negative aspect, i.e., an absence of pathological symptoms like tension, anxiety, depression, emotional imbalance, antisocial habits, drug addiction, etc. A person who does not display these symptoms is regarded as mentally healthy. This operational definition of mental health seems to be quite good since it is tied up with normality. It is assumed that a normal person is well-adjusted and therefore must have good mental health. However, a difficulty arises about the term "normality" itself, It does not have an independent existence. It exits only with reference to a particular culture in which one lives. Since different cultures vary considerably, there is no common standard of normality. This argument leads us to the con- 
clusion that a universally accepted definition of mental health is not possible.

Like the negative characteristics of mental healch, some psychologisis have also prepared a lise of positive qualities of mental health. This mechod also is nol very reliable. This is because one has to believe what a person says about himself, e.g., a mentally healthy person has a healuhy oullook lowards life. If he responds positively 10 the question, "Do you feel satisfied with your life?" we have no right to question his response. This is true ol all other positive qualities like sociability, emotional maturity, effectiveness of human relacionship. etc.'

In modern psychology several more or less independent systems explaining liuman nature have cmerged. Each system iries to solve ine complexity of human nature and many problems arising out of it. Most of these problems are concerned with mental health, especially with ils negative aspecl. These differeni systems of psychology can be grouped into three models viz. the mechanical, the dynamic, and the humanistic, brielly described as follows.

1. The mechanical model looks upon man as a reacijve being. It considers man as merely one more creature of nature whose behavior cen be undersivod, predicied, and controlled through processes such as conditioning, reinforcement. generalization. This model uses the stimulusresponse (S-R) formula with its several modificalions as its guiding principle in the study of various human problems, including mental health.' Most of the great experiments of tbis model are based upon laboratory animals, not on human beings. The model finds acceptance among scientists because of its claim 10 be a scientific method. "Iis methodology is no doubt scientific. but its primary postulate that man is simply a reaclue organism is not scientific. It has failed to give any effective soluzion 10 mental healch problems.

2. The dynamic model is best represented by the analytical schools of psychology founded by Sigmund Freud. According 10 this model, behind the kindly exterior world of man there lurk impulses, urges and wishes which man is ashamed 10 recognize. Since man, by his nature is an animal, he is 10 repress such impulses for his social and culiural adjustment. Scveral defence mechanisms make such adjusiment possible. Of greal imporlance are the in nucnces of childhood experiences. especially those which are sexual in nature and occur af different stages of developenent. Each stage is dominated by a special mode of achieving maximum pleasure. The secret of mental health is nol to repress live animal desires so that the mental conflict, which is the roor cause of maladjusiments, is avoided."

3. The humanistic model, which looks upon man as being in the process of "becoming", lays special emphasis on man's nature as lending loward selfdirection and self-fulfillmenl. The signiticant factor which affects the individual is nor so much reality, but rather what he experiences as reality. This means that reality for any individual is basically the private world of his own perceptions. The organized and consistent self is dcveloped through his experiences, gained as the result of interaction with others. Unimportant experiences are ignored aud those which are accepcable are incorporated into the self-siructure. The unaccepable experiences later prove inreasening to the self, which requires protection from such threals. The self becomes more rigid as more protection is needed. A person becomes maladjusled when he finds himself at odds wish his important experiences. Tension makes (he situation even worse and as a result he loses his menial health."

If we examine these models carefully, it will become obvious that they are based upon the assumption that man is like all olher creatures, a creature in this universe who has allained the highest state of oevelopment through the evolutionary process. In other words, the basic urges of man arc common among animals and human beings. One modern system, at least, cries 10 remove the mask and let the person have free expression of his feelings and desires. Or course, all these models give appropriase atrention to the problem of mental health, but fail to five any effective solution to the problem of mainrairring or regaining mental health.

Another facl can not be ignored: in all advanced countries, especially in the Uniced States, where different cypes of psychotherapies have been developed and used, the number of maladjusted and mentally disturbed people is increasing every year.' This shows that these current models, in spite of their experimental bascs, have not been able to go very far in solving the mental health problem, either at individual or at naicional levels. The inadequacy of these models obviously is due to the fact that they have not been able 10 give a Irue piclure of the human nature, specifically the spiricual aspect, without which psychologisis cannot understand man's original nature. Hence, there is a need for another inodel which could explain human nature from a different angie.

The modet that gives a irue piciure of human nature and explains the problems of mental healih, giving proper attention to the spiritual aspect, is the Islamic madel. We believe this model will find support noe only from Muslim pscyhologists. Who are blindly following the old models, bur also from nonMuslim psychologists as well, who will discover many revealing facis.

Islam as we all know, is not a religion in the ordinary sense, bue is a "Din", i.e., a way of living in accordance with the laws of God (Allăh). In the Qur'àn one reads. 
"The religion before Allăh is Islam." "

Islam means complete submission 10 the will of Aljăh, ihus the cnjoyment of peace. The Qur'àn clearly siates.

"Aod 10 Allah submits whosever is in the heavens and the earth willingly or unwillingly..."

In oiher words, every creature on earh is bound 10 obey the laws of nature by following the path of "Din-ul-fierah". Deviacion from this pach resules in maladjustment. This "firrah" or "instincr" has been referred 10 in the Qur'an:

"So sel your face truly to the faith, according 10 the pattern on which he has made mankind..."

In order to understand the nature of the Islamic model the following points are worth noring. since these are its basic principles.

1. Man is nor a reactive being or a slave of his urges. but he is created in the best way:

"Surely We created man of the best stacure."."

Indeed man is a viceroy. Alläh says:

"Behold Thy Lord said to the argeis: "I will create a vicegerent on Earth..." "."1

As such, he (man) portrays godly qualitics. Human nature cannot be explained without referring to his spiritual aspece. Indeed, that is the vital aspece of man that makes him "khalifah" or vicegetent on earth.

2. Mar is created with some purpose. His life is not merely that of birth, eating, sleeping, maturing, mating, growing old, and dying. The Qur'ān says about man:

"Did you think that We had crealed you wilhout purpose and that you would not be brought back 10 us 'for account'?"'s

Later on we read in the Book that the real purpose of his creacions is 10 seek Allâh's pleasure.

3. Man is nol a machine as the mechanical model insists. He is given the gift of freedom 10 an in any way he likes. He is, however, warned that all his actions, right or wrong, will be judged in the next life and that he wijl be rewarded accordingly.

in light of these principles, the nature of mental health can be explained in a more effective manner. Allāh says:

"... All creatures in the heavens and on earh have willingly or will unwillingly bow to His wil\}." It
Since the entire creation obeys the laws of Allãh, the whole universe literally follows "Dïn-ul-Isläm". i.e., obedience and complele subnission to Alläh, the Lord of the universe. This also implies thas even in the human world the laws of nature are quice manifest. All the organs of his body, including his heart and brain, are following the path of Islam. This means that they follow the course that has been ordained for them. However, man has another position as well. On one hend, he is regulated by the Divine law and as such he is a born Muslim; but on the other hand he has been given the freedom of thought, choice, and action, and because of this he can chalk out his own course of behavior.

Both these aspects coexist in man's life. If he consciously decides 10 submit himself to the will of Allāh in the domain in which he is given freedom of choice, he experiences no conflict in his personalicy. He is a Muslim consciously as well as uncounsciously. "Such a person belongs 10 what the Qur'an describes as "Ummalan Wasalan", i.e., people who are jusily balanced. These people are "muflihin", those who prospser in their lives. Alsāh describes them as follows:

\section{"They neither worry nor suffer from grief."."}

On the olher hand, those who despite being unconsciously Musljms. do nol exercise their higher mental functions for recognizing cheir Creator, and misuse their freedom of choice by denying bim and nor submitcing 10 His will are in a stare of mental conflict. The inevitable consequences of this conflict is a failure in the ultimate ideals of life. Their personality becomes disintegrated and ineir mental health is shatered.

Islam does not consider mental health as only the absence of palhology, but also emphasizes the posilive aspect by which mental health can be maintained and improved. The following points further explain the positive aspect of mental health.

1. The Islamic medtal health program does nol recommend the suppression of human urges but insists on keeping balance among them. This concepl is best illustrated in the Qur'än by use of the term "Sawā'-a)-Sabil"., or "right/straight pain", which is the path of straighiforwardness and moderation "I'tidâl". This means no urge is given undue importance at the cost of other urges. This results in a fulty funcioning personality, a personality which is able to deal with all personal and social problems adequately. A person is thus saved in many crisis producing situations."

2. One of the major precipitating causes of mental ill health is the feeling of frustration and despair due to the presence of envy and jealousy. As a result, man's life is shadowed by anxiety, enmity. depression, etc. As a Muslim, be is directed not $10 \mathrm{com}$ - 
pare himself with others. The Qur'ān says:

"And in no wise covel those things in which Alláh has beslowed His gifts more freely on some of you than on others... But ask Allahn of His bounty ..."

In order to attain such a state of mind, the "mullihin" inculcate ecrsain values like patience and gralitude. We read in the Qur'àn:

"Lo, verily man is in a stace of loss, save those who believe and do righteous deeds and exhor one another to truth, exhort one another to endurance. "'o

Wlyen in uller grief and despair, reading the Qur'ānic versé,

"To Allah we belong and to Him is our return"

works like a miracle.

3. In the dynamic model, the concept of guilt plays an importanr role in repression, a mechanism that is the root cause of many troubles. Islam on the ocher hand, has introduced the concept of "tawbah" (repencance). In the Qur'ân one reads,

"Your Lord has prescribed from Himself mercy. Those whom of you doeth evil and repenteth afterwards and docth right. for him Alläh is forgiving and merciful."."

4. Isłam encourages cerlain spirinual values like siraightforwardness, righteousness, elc. The importance of these values in promoting mental health cannot be denied.

s. Some emotions, like rage, are responsible for some types of psychosomatic illness. Musfims are directed to control their emolions. Allāh describes some of the qualicies of believers:

"Those who restrain anger and pardon all men and Allàn loves lisose who do good." ")

6. It is the obligation of every man co keep normal relations with bis relatives and others. The secrel of mental health lies in observing cerrain rights and obligalions. These include righis of other people over him. A healıhy person is one who fulfills his personal as well as social duties 10 the best of his effory. "The following beautiful verse is his code of conduct:

“Alläh cornmands justice. the doing of good, and liberality, as is kindness to kith and kin, and He forbids shameful deeds and injustice and rebellion. He instructs you that you may receive admonition." ":

By reading this verse again and again one will realize that a person whose behavior is motivased by these two goals, the development of some positive acts ano avoidance of cerlain deeds, remains free from worries and anxielies. Psychologists agree on this point, thet a welladjusted person is one whose personal as well as social life is well-regulated.

7. Islan gives due importance to the spiritual aspeci of life. Whenever a Muslim is in crouble, he is asked to turn to Allāh. Alläh says,

"Those who have believe, and whose hearts find. rest and satisfaction in the rememberance of Alläh. Verily in the rememberance of Allan do hearts find rest and tranquility."."

This is an attempl 10 give a brief outline of the Islamic concepl of mental heatth. $\|$ is for young psychologisis 10 develop these ideas further and 10 give them proper shape. In this age of fierce turmoils, when modern psychology has failed lo give peace of mind, the lslamic viewpoint will be a Cod sent gift. I am sure both Muslim and non-Muslim psychologists will find the Islamic model more effective than any olher model.

The test for the superiority of this model lies in a comparative study of Muslim and non-Muslim worlds with respect 10 mental health problems. It is assumed that Muslim socicties face considerably less mental health problems than the non-Muslim socielies.

\section{References}

1. Selya H. The Stress of Life. 2nd Ed. New York: McGraw-Hill, 1976: Chapler 1.

2. Alawi AH. Zehni Sehar (Urdu), Ch. I The Importance of Mental Behavior, Lahore (Pak): Psyche Forum, 1988; pp 9-15.

3. Price RH. Abnormal Behavior. 2nd Ed. New York: Holt, Rinehart, 1978; Chapler 5.

4. Alawi AH. Presiden(ial Address of Educcional Psychology, Guidance of Counseling Secrion. "Need for Re-evalusion of Currenr Counseling. Models", Pakiscan Psychological Association, $1978 ; p 6$.

5. World Book Encyclopedia. Vol. Is. "Psychoanalysis" and "Psychology". New York: World Book Co., 1988.

8. Rogers C. On Becoming a Person. New York: Houghlon-Mifnin, 1961.

7. Myers DG. Psychology. New York: Worih Publishing Co., 1989. p. 445.

8. Glorious Qur'än, Chapler 3, Verse 19. 
9. Glorious Qur'än, Chapter 13, Verse 15. 10. Glorious Qur'ān, Chapter 30, Verse 30.

11. Glorious Qur'àn, Chapter 95, Verse 4.

12. Glorious Qur'àn, Chapier 2, Verse 30.

13. Glorious Qur'ăn, Clapter 23, Verse 115.

14. Glorious Qur'an, Chaper 3, Verse 83.

15. Maudū di AA. Towards Understanding 1slant. 11th ed. "The Meaning of Istano". Lahore: Publicarions, Ltd., 1967; Chapter 1.

16. Glorious Qur’ān, Cbapter 2, Verse 38.

17. Maudüdi AA. Tarhim-ul-Qur'àn (Uirdu) $8 \mathrm{th}$ printing, Vol. I. Lahore: Idara-i-Tarjumanul Qur'àn; 1988; p.p. 452-454.

18. Glorious Qur'ān, Chapter 4, Verse 32.

19. Glorious Qur’ān, Chapter 103, Verse 2-3.

20. Glorious Qur’än, Chapter 2, Verse 156.

21. Glorious Qur'ān. Chapter 6, Verse 54.

22. Glorious Qur'ān, Chapter 3, Verse 134.

23. Maudüdí AA. Tafhìm-ul-Qur'än, Volume 2, Lahore, Pakislan, 1982, p 544-6.

24. Glorious Qur'ān, Chapter 16. Verse 90.

25. Glorious Qur’ān, Chapter 13, Verse 28. 